DOI: https://doi.org/10.24127/ajpm.v9i3.2907

\title{
MATHEMATICS LEARNING: BUILT THE INDEPENDENCE OF STUDENT USING PROBLEM-BASED LEARNING
}

\author{
Reni Dwi Susanti ${ }^{*}$, Marhan Taufik ${ }^{2}$ \\ $1^{*, 2}$ Universitas Muhammadiyah Malang, Malang, Indonesia \\ *Corresponding author. Jl. Raya Tlogomas No. 246, 65144, Malang, Indonesia. \\ E-mail: $\quad$ renidwi@umm.ac.id $\left.{ }^{1 *}\right)$ \\ $\underline{\text { marhan@umm.ac.id }}^{2}$
}

Received 03 July 2020; Received in revised form 11 September 2020; Accepted 26 September 2020

\begin{abstract}
The purpose of this study is to describe how Problem based learning to train student independence. This type of research used a descriptive with a qualitative approach. Data collection techniques using observation and questionnaires. The study was conducted on students who were taking Basic Logic courses, totaling 23 students. Data analysis techniques by data reduction, data presentation, and concluding Problem Based Learning. The results showed that the average implementation of learning with Problem Based Learning was $86.83 \%$, and the learning independence of students from the observations was $62.29 \%$ which was included in the good category supported by the results of the questionnaire independence with an average of $70.78 \%$ which in the high category. These results indicate that learning by using Problem Based Learning can be used to train student independence. The independence aspect that is emphasized is self-confidence, motivation, have responsibilities, discipline, and initiatives that arise during the learning process. Besides that, by applying the Problem Based Learning, the learning process involves students to take an active part, besides that students are also given more responsibility in the continuity of the learning process and their understanding.
\end{abstract}

Keywords: Independence learning; mathematics learning; problem based learning.

This is an open access article under the Creative Commons Attribution 4.0 International License

\section{INTRODUCTION}

Independence in learning is one of the important factors that can influence student success in learning (Suhendri \& Mardalena, 2015). The level of independence can have an impact on learning outcomes at school given that independence is a personal attitude possessed by each student. Self-study independence can be interpreted as a learning activity that stands alone without help from others, such independence can include independence in understanding the material or solving problems in everyday life (Suhendri, 2011) (Sundayana, 2018).

The indicators of learning independence include such as having a sense of responsibility, not dependent or dependent on others, having great curiosity, and having an attitude of confidence (Simanullang, 2017) (Murni \& Khotimah, 2013). The development of students' learning independence is very important to do because it can be used as the main capital to become an independent person in daily life and can be used to prepare themselves to face various changes and problems that occur due to the influence of the development of science and technology (Runisah, 2018). Based on the results of the initial observations of student learning independence when learning activities get mixed results. However, of the 23 students, there were only 3 who 
were able to study on their own to understand the material, 20 other students waited for an explanation from the lecturer to be able to understand the material.

When learning activities lecturers already use methods or models of group learning and are no longer conventional. But students still depend on the lecturer in understanding the material and depend on other students who are considered smart. Especially when working on practice questions. So that it results in fewer learning outcomes. It also shows that the independence of student learning is very less. In addition, there are also other factors that cause it. (Suhendri, 2011), explained that one of the factors that influenced mathematics learning outcomes was the learning method. In addition to independence in learning, certainly learning methods also need to be considered in pursuing active learning.

Mathematics learning methods in the revised edition of the 2013 curriculum put forward thematic and integration aimed at encouraging students to be able to carry out observations, ask questions, reason, and communicate what they know and get after receiving learning materials in school (Anwar, 2014). Another factor that can affect the quality of learning in mathematics is the ability of lecturers to create conditions for active learning. Not only emphasizes the ability to memorize formulas and speed calculations, but a lecturer must be able to help students understand and reason. Efforts that can be used to train the independence of learning in students is to use appropriate learning models or methods.

One method of learning that can train students' learning independence is Problem Based Learning. Problem
Based Learning is one of the learning methods that can be used in learning. Problem Based Learning emphasizes the learning process that asks students to learn their own material and develop their own skills but remains under the supervision of lecturers (Ommundsen, 2013). Problem Based Learning not only emphasizes solving mathematical problems but also how to understand the correct concepts (Hmelo-Silver; et al., 2006). In this learning method, students are asked to study with a group of friends to solve a problem, where the problem requires students to understand concepts, reason, develop skills, and communicate.

There are several previous studies that have sought to improve student learning independence, namely research by (Lestari et al., 2019) which states that there is an influence of the use of Situation-Based Learning models and learning independence of mathematical problem-solving abilities. Research by (Febriastuti et al., 2015) applies a project-based inquiry learning model or Problem-based learning to physics lessons in which its application can improve student learning independence. (Munawaroh et al., 2012) stated that the application of the Problem-based learning model is more capable of building four pillars of learning (learning to know, learning to do, learning to live together, and learning to be) than cooperative learning models. Based on research that has been carried out, it can be seen that the Problem Based Learning (PBL) learning model can be used as an effort to train students' learning independence.

Based on the description above, to assist students in practicing learning independence is to use the problembased learning method of learning. With Problem Based Learning, students are 
expected to be able to understand concepts and solve problems without relying again on the lecturer's explanation. And students will be more active in learning and discussing. Based on the problems that have been described, the purpose of the research is how the implementation of Problem Based Learning in training student independence and whether the Problem Based Learning learning model can be used to train student independence.

\section{RESEARCH METHOD}

This research uses descriptive research with a qualitative approach. The research subjects were 23 students who took the Basic Logic course in the Mathematics Education Study Program, University of Muhammadiyah Malang. The research procedure used starts with a needs analysis which includes problem analysis and literature study, then continues with the preparation of research instruments and then data collection is carried out. After data collection, analysis is carried out according to the needs of the problem formulation.

Data collection methods of this research were observation and questionnaire. Observation aims to see how the implementation of learning activities by using of Problem Based Learning and to see how the independence of student learning. While the questionnaire is used to retrieve data about how the independence of student learning in understanding the material. The research instrument used in this study was the observation sheet of the implementation of learning and a questionnaire to measure student learning independence by applying the Problem Based Learning learning method.
Data analysis was performed using the Milles and Huberman technique, which includes data reduction stages, namely by sorting data according to its type, for example, data from observations of learning performance and student grades and data from the questionnaire results, presenting data by finding the average of each instrument and then presented in the form of a table.

Withdrawal conclusions from the data obtained and then adjusted to the purpose of this study are to process the questionnaire results data and observation sheets which are further described supported by the findings at the time of observation.

\section{RESULT AND DISCUSSION}

\section{Learning Activity with Problem-Based} Learning

The research activity was carried out in a Basic Logic class consisting of 23 students. In implementing their learning, the lecturer applies the Problem Based Learning method for 2 meetings. In its implementation lecturers give problems and ask students to study in small groups. Then the lecturer conducts guidance by visiting each of the groups. So students coordinate each other to solve the problems given by the lecturer. The results of the observation learning activities will be presented in Table 1 .

Table 1: Observation Results Learning activities

\begin{tabular}{lllll}
\hline Meet & \multicolumn{3}{l}{ Learning Activity } & Average \\
\cline { 2 - 4 } & Early & Core & End & \\
\hline 1 & $90 \%$ & $87 \%$ & $82 \%$ & $86,33 \%$ \\
2 & $92 \%$ & $88 \%$ & $82 \%$ & $87,33 \%$ \\
Average for first & meeting and & $86,83 \%$ \\
second meeting & & & \\
\hline
\end{tabular}

The activity at the initial stage in the lecturer opened the lesson very well 
can be seen in the table, the average percentage at each of them was more than $90 \%$. If seen from the first and second meetings there was a slight increase from $90 \%$ to $92 \%$ this difference occurred because at the first meeting the lecturer did not convey the material outline. However, the average percentage obtained in the initial stages has shown that learning activities in the excellent category.

The average percentage at the first meeting was $87 \%$ while in the second meeting was $88 \%$, at this stage the core activity of lecturers had increased. In implementing Problem Based Learning, it can be seen that in the learning step the lecturer acts as a walking facilitator providing guidance to students so that they complete their assignments well and students are directed to always work together during the problem-solving process given by the lecturer. The next activity carried out by students is to carry out presentations on the results of project reports that have been completed. The enhancement in learning activities occurred because at the second meeting the lecturers had made improvements from the shortcomings during the first meeting.

In the final stage of learning, for the first and the second meeting, implementation of learning obtained the same average of $82 \%$. The learning implementation of the lecturer reflects the learning activities taking place and provides information about the activities that will be carried out at the next meeting. As well as encouraging students to draw conclusions and convey learning experiences that have been implemented then close the learning with prayer and greetings.
Table 2. Observation of student independence in problem based learning learning.

\begin{tabular}{|c|c|c|c|}
\hline \multirow[t]{2}{*}{ Aspect } & \multicolumn{2}{|c|}{$\begin{array}{l}\% \text { independence of } \\
\text { learning at each meetin }\end{array}$} & \multirow[t]{2}{*}{$\begin{array}{c}\% \\
\text { Average }\end{array}$} \\
\hline & 1 & 2 & \\
\hline Confidence & 58,3 & 64,6 & 61,45 \\
\hline Motivation & 57,3 & 63,3 & 60,3 \\
\hline Responsible & 61,5 & 65,3 & 63,4 \\
\hline Discipline & 61,7 & 64,9 & 63,3 \\
\hline Initiative & 64 & 62 & 63 \\
\hline Average & 60,56 & 64,02 & 62,29 \\
\hline
\end{tabular}

In addition to observing the implementation of learning in general. Observations were also made to see the level of independence of student during learning proccess by applying Problem Based Learning. The results of the observations can be seen in Table 2 .

Based on the results of the independence observation table when learning with Problem Based Learning, the confidence aspect on the first and second meetings obtained an average percentage of $58.3 \%$ and $64.6 \%$. The first meeting, students is not optimal in conveying the percentage, especially on the indicators of students being calm in everything in learning. But students can ask or answer questions, then students are enthusiastic when following the learning process. Self-confidence in question is the ability of students to socialize by asking a number of things related to the data collection process.

The second aspect is motivation, the acquisition of the average percentage shows that the independence of students is still classified in the quite good category with the results of the percentage of $57.3 \%$ and $63.3 \%$. In this aspect, students are less than optimal on indicators capable of completing project assignments earlier than other friends (competitive) and students have the 
ability to lead. This is because students assume that the most important thing is all the tasks are answered and completed even though it is not the first. The motivational aspect arises when students in the process of doing assignments have the ability to lead by dividing each part of the task fairly and evenly

The third aspect is responsibility while the average percentage at each meeting has a result of $61.5 \%$ and $65.3 \%$. This shows that in the learning process students have a high sense of responsibility to complete their assignments. are students in each group participating in implementing and solving problems that arise during the process of completing a project and have a sense of concern for the project assignments obtained, in addition students are also required to cooperate with each other because each student must be given the mandate or responsibility of completing the project seen from the list of division of tasks performed in each group. Students are also seen answering all the questions in the questions and in the presentation activities students tend to be seen to understand the concept of the material being explained.

The fourth aspect is discipline while the average percentage obtained by students at each meeting is $61.7 \%$ and $64.9 \%$. In this aspect students do not delay the assignment given by the lecturer and students do not cheat the work of other friends in doing the assignments given by the lecturer get a good average and students do the assignments on time. The disciplinary aspect is also seen when students do not procrastinate but stay focused on the project work

The fifth aspect is initiative while the average percentage obtained by students at each meeting is $64 \%$ and $62 \%$. By implementing Problem Based Learning students look more initiative in completing their assignments. The attitude shown by students is initiative because every student can be active in completing projects and have more encouragement such as asking how the verification process is where students still feel difficulties. Then students also ask how to use the rules of drawing conclusions in the proof, of course this is based on the urge of curiosity so that students can master things that have not been understood. In addition, students complete their assignments not only using the steps or methods described by the lecturer, but by looking for other materials or reading other references, students get a solution or other means.

Based on the results that have been explained, it can be seen that in general the total average percentage of observations on student independence at the first and second meetings are $60.56 \%$ and $64.02 \%$. This shows that learning with Problem Based Learning can be used to train student independence, because each step of the Problem Based Learning has aspects of independence starting from determining the basic questions until evaluation which always involves students to be active in learning from the begining until the end of activities students are given more responsibility in the sustainability of the learning process.

As stated by (Idrus, 2018) students who have independence in learning will show positive attitudes that are reflected in their learning. This is also in line with research conducted by (Lestari et al., 2019) which also state that independent learning influences the problem-solving process of the students. There is a positive attitude that is shown by students who are tough when facing 
difficulties and keep trying to complete the task. From the process of completing assignments, students can socialize each other in the class which can practice communication skills besides the independence shown by students is confidence, responsibility, discipline, and motivation.

\section{Student Independence Learning Questionnaire}

In addition to the observation stage of the continuity of the learning process Problem Based Learning in practicing student learning independence also conducted data collection using a questionnaire. The questionnaire aims to see how the process of learning independence experienced by students themselves. The aspects seen in the questionnaire are the same as the observation questionnaire, which includes selfconfidence, motivation, responsibility, discipline, and initiative possessed by students. The percentage of overall results of the questionnaire that has been filled out by students will be presented in the following Table 3.

Table 3. Results of analysis on student independence questionnaire.

\begin{tabular}{lc}
\hline Aspect & \% Independence of students \\
\hline Confidence & 70,5 \\
Motivation & 67,7 \\
Responsibility & 73,3 \\
Discipline & 70,2 \\
Initiative & 72,2 \\
Average & 70,78 \\
\hline
\end{tabular}

Based on Table 3 it can be seen that the average achievement of students' independence is $70.78 \%$ or good category. The responsibility for getting the highest percentage is $73.3 \%$. While Motivation only gets $67.7 \%$.

The results of the questionnaire are directly proportional to the results of direct observations of the learning independence of students with the implementation of Problem Based Learning. The highest percentage is Responsibility aspect and the lowest is motivation and the lowest in the aspect of motivation. This is also supported of the findings during the observation which shows that the implementation of Problem Based Learning encourages students to practice communication skills and ask questions. Then students also learn how to allocate time, and process data so that a conclusion can be drawn or get an answer of the-given problem, for example, is how to use the rules of drawing conclusions or rules of exchange in finding the conclusions of an argument. This is also in line with research conducted by (Mahendra, 2017) which revealed several advantages in learning Problem Based Learning, namely in learning mathematics, student motivation becomes more improved, students' ability to collaborate increases, encouraging students to be active and learning becomes more enjoyable, students can practice communication skills, organize projects and are more interested in carrying out discussions so that students are always involved in the learning process.

Problem Based Learning Learning gives more responsibility for the continuity of the learning process, students can explain again what has been done through presentations and can collect, classify, process, and present data independently. Based on this, it can be concluded that the independence of students in learning can arise in every step of learning by using Problem Based Learning. This is also consistent with research (Lestari et al., 2019) where project-based learning or Problem Based Learning can be used to improve or train students' independence. 


\section{CONCLUSION AND SUGGESTIONS}

Based on the description of the results of the study, the students' learning independence using Problem Based Learning is generally very well implemented. This is supported by the average results of the percentage of learning activities during the implementation of Problem Based Learning, which is $86.83 \%$, which means the lecturer can manage learning by implementing Problem Based Learning well and students can also take part in learning activities that aim to practice self-learning also very good. To create very good learning activities and also train the student's independence and can train student learning independence.

Independence of students also showed good results, namely the results of observations that have been carried out on average with a percentage of $62.29 \%$ supported by the results of the questionnaire independence which obtained an average percentage of $70.78 \%$. This reinforces the results of the first problem formulation that is by applying Problem Based Learning can be used to train student independence because in the learning process always involves students to be active in learning from the beginning to the end of the activity, besides, students are also given more responsibility in the sustainability of the learning process

Suggestions that can be given for further research related to this research are so that other researchers can see students' independent learning in other aspects and by using different learning models. For teachers, in order to use this learning model in teaching, so that students' independent learning can be known.

\section{REFERENCES}

Anwar, R. (2014). Hal-Hal yang Mendasari Penerapan Kurikulum 2013. Humaniora, 5(1), 97. https://doi.org/10.21512/humaniora .v5i1.2987

Febriastuti, Y. D., Linuwih, S., \& Hartono. (2015). PENINGKATAN KEMANDIRIAN BELAJAR SISWA SMP NEGERI 2 GEYER MELALUI PEMBELAJARAN INKUIRI BERBASIS PROYEK. Unnes Physics Education Journal, 4(3), 44-49. https://doi.org/http://dx.doi.org/10. 1089/ars.2015.6320

Hmelo-Silver;, E., C., \& Barrows, H. S. (2006). Goals and Strategies of a Problem-based Facilitator. Learning Interdisciplinary Journal of Problem-Based Learning, $1(1)$. https://doi.org/10.7771/15415015.1004

Idrus, E. (2018). Membongkar Psikologi Belajar Aplikatif. Guepedia Publisher.

Lestari, I., Andinny, Y., \& Mailizar, M. (2019). Pengaruh Model Pembelajaran Situation Based Learning dan Kemandirian Belajar Terhadap Kemampuan Pemecahan Masalah Matematis. JNPM (Jurnal Nasional Pendidikan Matematika), 3(1), 95. https://doi.org/10.33603/jnpm.v3i1 .1748

Mahendra, I. W. E. (2017). Project Based Learning Bermuatan Etnomatematika Dalam Pembelajar Matematika. JPI (Jurnal Pendidikan Indonesia), 6(1), 106114. https://doi.org/10.23887/jpiundiksha.v6i1.9257 
Munawaroh, R., Subali, B., \& Sopyan, A. (2012). Penerapan Model Project Based Learning Dan Kooperatif Untuk Membangun Empat Pilar Pembelajaran Siswasmp. UPEJ (Unnes Physics Education Journal), l(1). https://doi.org/10.15294/upej.vli1. 773

Murni, E. N., \& Khotimah, R. P. (2013). Optimalisasi strategi pembelajaran siklus untuk meningkatkan kemandirian dan prestasi belajar matematika (. Seminar Nasional Pendidikan Matematika Surakarta, 82-88.

Ommundsen, P. (2013). Problem-based learning. In Inspiring Students: Case Studies on Teaching Required Courses (pp. 25-32). Taylor and Francis. https://doi.org/10.4324/978131504 2169-9

Runisah. (2018). Peningkatan Kemandirian Belajar Matematika Siswa SMP melalui Model Learning Cycle 5E Dengan Teknik Metakognitif. Jurnal Edukasi Dan Sains Matematika (JES-MAT), 4(1), 13-24.

Simanullang, B. (2017). Mengembangkan Kemandirian Belajar, Kepercayaan Diri, dan Pengaruhnya terhadap Kemampuan Pemecahan Masalah Matematika. Jurnal Ilmiah WIDYA Eksakta, 1(1), 62-69.
Suhendri, H. (2011). Pengaruh Kecerdasan Matematis-Logis dan Kemandirian Belajar terhadap Hasil Belajar Matematika. Formatif: Jurnal Ilmiah Pendidikan MIPA, l(1). https://doi.org/10.30998/formatif.v $1 \mathrm{i} 1.61$

Suhendri, H., \& Mardalena, T. (2015). Pengaruh Metode Pembelajaran Problem Solving terhadap Hasil Belajar Matematika Ditinjau dari Kemandirian Belajar. Formatif: Jurnal Ilmiah Pendidikan MIPA, $3(2)$.

https://doi.org/10.30998/formatif.v 3i2.117

Sundayana, R. (2018). Kaitan antara Gaya Belajar, Kemandirian Belajar, dan Kemampuan Pemecahan Masalah Siswa SMP dalam Pelajaran Matematika. Mosharafa: Jurnal Pendidikan Matematika, 5(2), 75-84. https://doi.org/10.31980/mosharafa .v5i2.262 